\title{
NEW RECORDS OF MYOTIS ALCATHOE IN UKRAINE
}

\author{
Andriy-Taras Bashta ${ }^{1}$, Igor Ivashkiv ${ }^{1}$, Artur Krokhmal ${ }^{2}$ \\ ${ }^{1}$ Institute of Ecology of the Carpathians, NAS of Ukraine (Lviv, Ukraine) \\ ${ }^{2}$ Ivan Franko National University of Lviv (Lviv, Ukraine) \\ Correspondence to: A.-T. Bashta; Institute of Ecology of the Carpathians, NAS of Ukraine, Kozelnytska St. 4, Lviv, \\ 79026 Ukraine; e-mail: atbashta@gmail.com
}

\begin{abstract}
New records of Myotis alcathoe in Ukraine. - A.-T. Bashta, I. Ivashkiv, A. Krokhmal. - A male Myotis alcathoe $(\mathrm{FA}=32,1 \mathrm{~mm}, \mathrm{D} 5=41 \mathrm{~mm}, \mathrm{G}=4,1 \mathrm{~g})$ was caught using mist-net on 12 September 2016 near the entrence of the Medova Cave $\left(49^{\circ} 49^{\prime} 16,3^{\prime \prime} \mathrm{N}, 2^{\circ} 05^{\prime} 23^{\prime \prime} \mathrm{E} ; 357 \mathrm{~m}\right.$ a.s.1.), which is located in the southeastern outskirts of Lviv city (Western Ukraine). This is the first record of M.alcathoe in the city of Lviv. Observations of $M$. alcathoe at the cave entrance during the swarming period confirms the use of underground shelters by this species for hibernation. The species is part of the bat communities of old deciduous forests, which was confirmed by ultrasound investigations in summer.
\end{abstract}

Key words: Myotis alcathoe, swarming, Lviv, Ukraine.

Нові спостереження Myotis alcathoe в Україні. - А.-Т. Башта, І. Івашків, А. Крохмаль. - Самець Myotis alcathoe $(\mathrm{FA}=32,1 \mathrm{mм}, \mathrm{D} 5=41 \mathrm{мm}, \mathrm{G}=4,1$ г) був зловлений за допомогою павутинної сітки 12.09.2016 р. на вході до Медової печери (4949’16,3”N, 2405’23”'Е; 357 м над р. м.), яка розташована на південно-східній околиці м. Львів (Західна Україна). Ця знахідка є першим підтвердженням наявності цього виду на території м. Львова. Спостереження особини M. alcathoe біля входу в печеру під час періоду «роїння» підтверджує можливість використання підземних схованок для гібернації. У прилеглих лісах $M$. alcathoe $є$ частиною угруповання кажанів старих широколистяних лісів, що підтверджене ультразвуковими дослідженнями у літній період.

Ключові слова: Myotis alcathoe, явище «роїння», Львів, Україна.

\section{Introduction}

Myotis alcathoe (von Helversen \& Heller, 2001) was first described at the beginning of the twentieth century based on specimens from Greece and Hungary. It became clear soon that the real distribution range of this Myotis species was much wider according to the range of new records from the Iberian Peninsula, France, Germany, Albania, Poland, the European part of Turkey (Niermann et al., 2007), Slovakia (Benda et al., 2003), the Czech Republic (Rehak et al., 2008), Ukraine (Bashta et al., 2010) etc. In Ukraine, M. alcathoe was first described as "Myotis ikonnikovi" (Bashta et al., 2010; Zagorodniuk, Emelyanov, 2012). The species was found recently in Transcarpathia and Western Podillia (Bashta et al., 2011; Bashta, 2014).

Myotis alcathoe still belongs to the poorly studied bat species not only in Ukraine, but also in the whole of Europe and our communication is intended to complement the existing information on the distribution and ecological features of this species.

\section{Material and methods}

Bat netting at the entrance of the Medova Cave was carried out on 12 September 2016, during the period of swarming. The Medova Cave $\left(49^{\circ} 49^{\prime} 16.3\right.$ "N, $24^{\circ} 05^{\prime} 23^{\prime \prime} \mathrm{E} ; 357 \mathrm{~m}$ a.s.1.) is located in the southeastern outskirts of Lviv (Western Ukraine) and was formed in Tortonian (Baden) limestones. The dimensions of the entrance: width $-8.2 \mathrm{~m}$, height $-2.8 \mathrm{~m}$. The total length of the corridors is about $54 \mathrm{~m}$ (Bashta et al., 2004). The net was installed at the entrance to the cave. The 
cave is located on the border of the Vynnyky Forest, formed by deciduous tree species, mostly 100150 years of age. Its territory has a large number of ravines of different size, with numerous springs and streams.

Bat species identification was carried out by a number of morphological characters (Dietz, von Helversen, 2004). They include red-brown furs (without golden tips, usually typical for M. mystacinus and $M$. brandtii), a brownish color of the faces and ears, and a shorter tragus (slightly lower than the upper margin of the indentation of the ear). In the summer, ultrasonic studies covered forest, meadow, and meadow-shrubby biotopes in the vicinity of Lviv city. Ultrasound detectors D-240x (Pettersson Elektronik $\mathrm{AB}$ ) and Batcorder (ecoObst $\mathrm{GmbH})$ were used. The analyses of records were made using the programs "BatSound" and "bcAnalyze."

\section{Results and discussion}

Near midnight on 12 September 2016, one individual (male) was caught at the entrance to the Medova Cave and identified as $M$. alcathoe $(\mathrm{FA}=32.1 \mathrm{~mm}, \mathrm{D} 5=41 \mathrm{~mm}, \mathrm{G}=4.1 \mathrm{~g})$. It was the first confirmation of the presence of this species in vicinities of Lviv city.

The surrounding habitats are typical for the settlement of this species. The slopes on which the cave is located are covered with deciduous forests and clearings. Most of the records of this species in Europe (Niermann et al., 2007; Lučan et al., 2009) indicate that M. alcathoe is a forest-dwelling bat species and prefers similar habitats: natural, mainly old ( $>100$ years) mixed and broadleaf forests with water reservoirs and riparian vegetation. Such habitats usually have a significant number of hollow trees, which provide shelters for many tree-dwelling bat species.

Observation of $M$. alcathoe at the entrance to the cave in the autumn, during the swarming period confirms the use of this type of underground shelters for hibernation (Ohlendorf, 2009). The wintering of this species in underground cavities is also confirmed by observation by V. Pokynchereda and A. Kusnezh (2014) in the Carpathians.

In the adjacent Vynnyky forest, M. alcathoe is part of the bat community of old deciduous forests, which was confirmed by ultrasound research during the summer periods. In general, due to the high frequency of echolocation signals, the identification of this species is relatively easy, since among the bats in this region the similar frequencies are typical only for M. emarginatus, the occurrence of which in this area is unlikely.

In total, 70 bat specimens were caught near the cave entrance during the night, $51 \%$ of which were Eptesicus serotinus, and the rest of them belonged to Barbastella barbastellus, Plecotus auritus, and Myotis myotis.

Thus, new records increase our knowledge about the distribution of $M$. alcathoe in the territory of Ukraine and within the European range of the species. In addition, the records of M. alcathoe confirm the occurrence of the species near Lviv, and thus the bat fauna of this city today includes 21 species.

\section{References • Література}

Bashta, A.-T., V. Mysiuk, V. Pokynchereda. 2004. Caves of the Northern part of the Eastern Carpathians and the Lviv province. Cave Fauna of Ukraine. Ukrainian Theriological Society, Kyiv, 153-157. (In Ukrainian)

[Башта, А.-Т., В. Мисюк, В. Покиньчереда. 2004. Печери Львівщини і Прикарпаття. Фауна печер Украӥни. Київ : Українське теріологічне товариство, 153-157.]

Bashta, A.-T., L. Pokrytiuk, P. Benda. 2010. Alcathoe's bat Myotis alcathoe - a new bat species (Chiroptera: Vespertilionidae) in Ukraine. Vestnik zoologii, 44 (6): 552.

Bashta, A.-T., M. Piskorski, R. Myslajek, A. Tereba, K. Kurek, K. Sachanowicz. 2011. Myotis alcathoe in Poland and Ukraine: new data on its status and habitat in Central Europe. Folia Zoologica, 60 (1): 1-4.

Bashta, A.-T. V. 2014. Bats of the National park "Pivnichne
Podillia" area: the first results of investigations. Nature of the Western Polissia and Adjacent Areas, 11: 304-309. (In Ukrainian)

[Башта, А.-Т. В. 2014. Рукокрилі (Chiroptera) регіону НПП «Північне Поділля» і прилеглих територій: перші результати досліджень. Природа Західного Полісся та прилеглих територій, 11: 304-309.]

Benda, P., M. Ruedi, M. Uhrin. 2003. First record of Myotis alcathoe (Chiroptera: Vespertilionidae) in Slovakia. Folia zoologica, 52: 539-365.

Dietz, C., O. von. Helversen. 2004. Illustrated Identification Key to the Bats of Europe: Electronic publication, vers. 1.0. Tuebingen, 1-72. https://goo.gl/UA9440

Lučan, R. K., M. Andreas, P. Benda, T. Bartonička, T. Březinová, A. Hoffmannová, Š. Hulová, P. Hulva, J. Neckářová, 
A. Reiter, T. Svačina, M. Šálek, I. Horáček. 2009. Alcathoe bat (Myotis alcathoe) in the Czech Republic: distributional status, roosting and feeding ecology. Acta Chiropterologica, 11: 61-69.

Niermann, I., M. Biedermann, W. Bogdanowicz, R. Brinkmann, Y. Le Bris, et al., 2007. Biogeography of the recently described Myotis alcathoe von Helversen and Heller, 2001. Acta Chiropterologica, 9: 361-378.

Ohlendorf, B. 2009. Aktivitäten der Nymphenfledermaus (Myotis alcathoe) vor Felsquartieren und erste Winternachweis im Harz (Sachsen-Anhalt). Nyctalus (N.F.), 14: 149-157.

Pokynchereda, V. F., O. V. Kusnezh. 2014. New records of Myotis alcathoe in the Carpathian biosphere reserve. Regional Aspects of Floristic and Faunistic Investigations: Proc. of Intern. Conf. Druk Art, Chernivtsi, 217-219. (In Ukrainian)
[Покиньчереда В. Ф., О. В. Кусьнеж. 2014. Нова знахідка нічниці крихітної (Myotis alcathoe) в Карпатському бioсферному заповіднику. Регіональні аспекти флористичних і фауністичних досліджень : Матер. Міжнар. наук.практ. конф. Друк Арт, Чернівці, 217-219.]

Řehák, Z., T. Bartonička, J. Bryja, J. Gaisler. 2008. New records of the Alcathoe bat, Myotis alcathoe in Moravia (Czech Republic). Folia zoologica, 57 (4): 465-469.

Zagorodniuk, I. V., I. G. Emelyanov. 2012. Taxonomy and nomenclature of mammals of Ukraine. Proceedings of the National Museum of Natural History, 10: 5-30. (In Ukrainian)

[Загороднюк, І. В., І. Г. Ємельянов. 2012. Таксономія і номенклатура ссавців України. Вісник Національного науково-природничого музею, 10: 5-30.] 